\title{
Imaging Features and Morphology of Synovial Chondromatosis of the Spine-Case Report
}

\author{
Irena V Boulytcheva*, Alexandra V Fedorova, Yana A Schipakchina and Natalya V Kochergina
}

NN Blokhin National Medical Cancer Center, Moscow, Russia

Submission: May 19, 2018; Published: June 18, 2018

*Corresponding author: Irena V Boulytcheva, NN Blokhin National Medical Cancer Center, Moscow, Russia, Email: irena@boulytcheva.com

\begin{abstract}
Primary synovial chondromatosis represents an uncommon benign neoplastic process with hyaline cartilage nodules in the synovial tissue of a joint tendon sheath or bursa. The nodules may enlarge and detach from the synovium. These loose bodies are responsible for many clinical symptoms. Numerous data is available about the synovial chondromatosis of the knee joint, followed by the hip and ankle. Although much has been written about synovial chondromatosis of the large joints, only few case reports of synovial chondromatosis of the spine reported in the English literature and there is no data at all in Russian medical literature [1,2]. Although synovial chondromatosis is generally considered to be benign, cases of condrosarcoma arising from synovial chondromatosis have been reported [3,4]. Synovial chondromatosis should be considered in the differential diagnosis when evaluating additional mass in epidural or paraspinal tissue adjacent to the facet joint, especially when there is evidence of bone erosion. Fluid or myxoid signal centrally with thin or nodular peripheral enhancement is also very characteristic. Compression on bone and nerves is caused by calcified loose or attached to synovium bodies.
\end{abstract}

Keywords: Synovial chondromatosis; Bone erosion; Hyaline cartilage; Loose bodies, Cartilaginous nodules

\section{Case Report}

\section{Clinical Data, Imaging studies, Histology}

A 61 year-old female presented with complains of a painful feeling in her back for about a year, during the last several months the pain symptoms progressively worsened. The patient was admitted to the N.N. Blokhin National Medical Cancer Center for prospective diagnosis and treatment strategy. The core biopsy with computer navigation was performed. Grossly, small fragments of grey-white irregular soft cartilaginous tissue were observed. Basic routinely processed slides showed discrete clusters of hyaline cartilage without prominent cytologic atypia of chondrocytes, small foci of dystrophic calcifications. Even without evidence of malignancy, the tissue was suggested to be "suspicious for low-grade chondrosarcoma" [5].

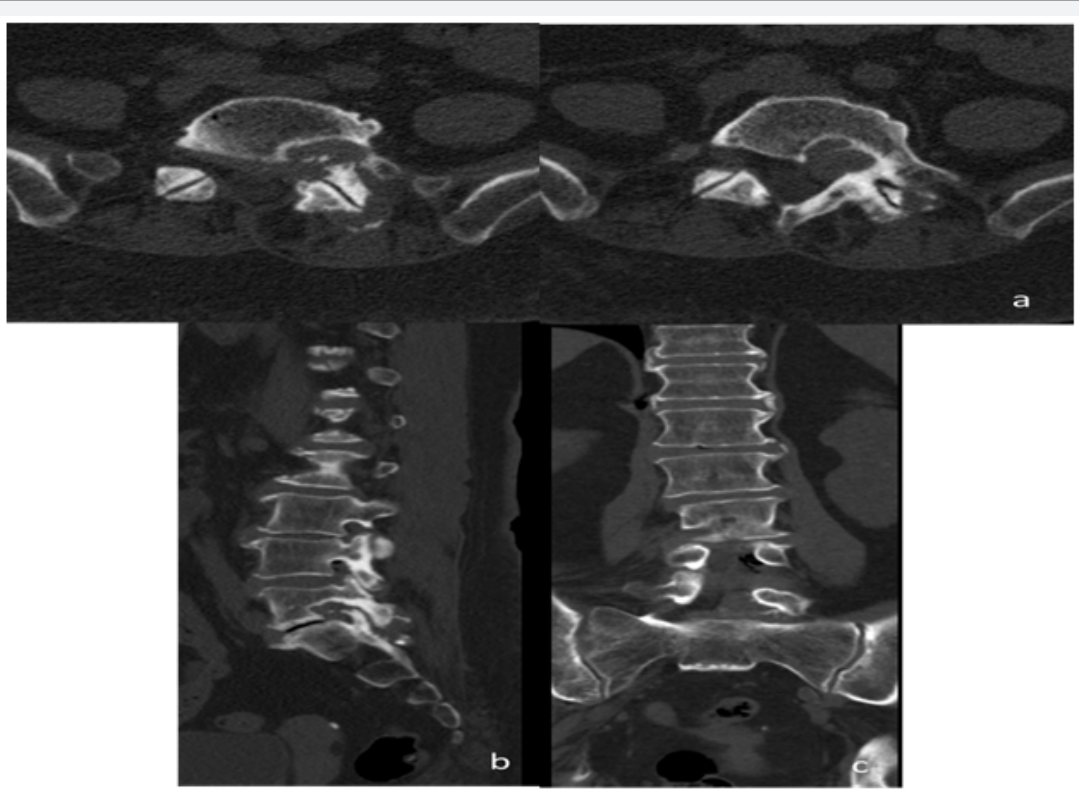

Figure 1: Axial CT (a) and coronal and sagittal reconstructions $(b, c)$ showing the soft tissue mass around the left L5-S1 facet joint containing characteristic calcifications and causing smooth erosion of left posterior cortex of the L5 vertebral body, left L5 pedicle, anterior and posterior surface of left L5-S1 facet joint. 


\section{Orthopedics and Rheumatology Open Access Journal (OROAJ)}

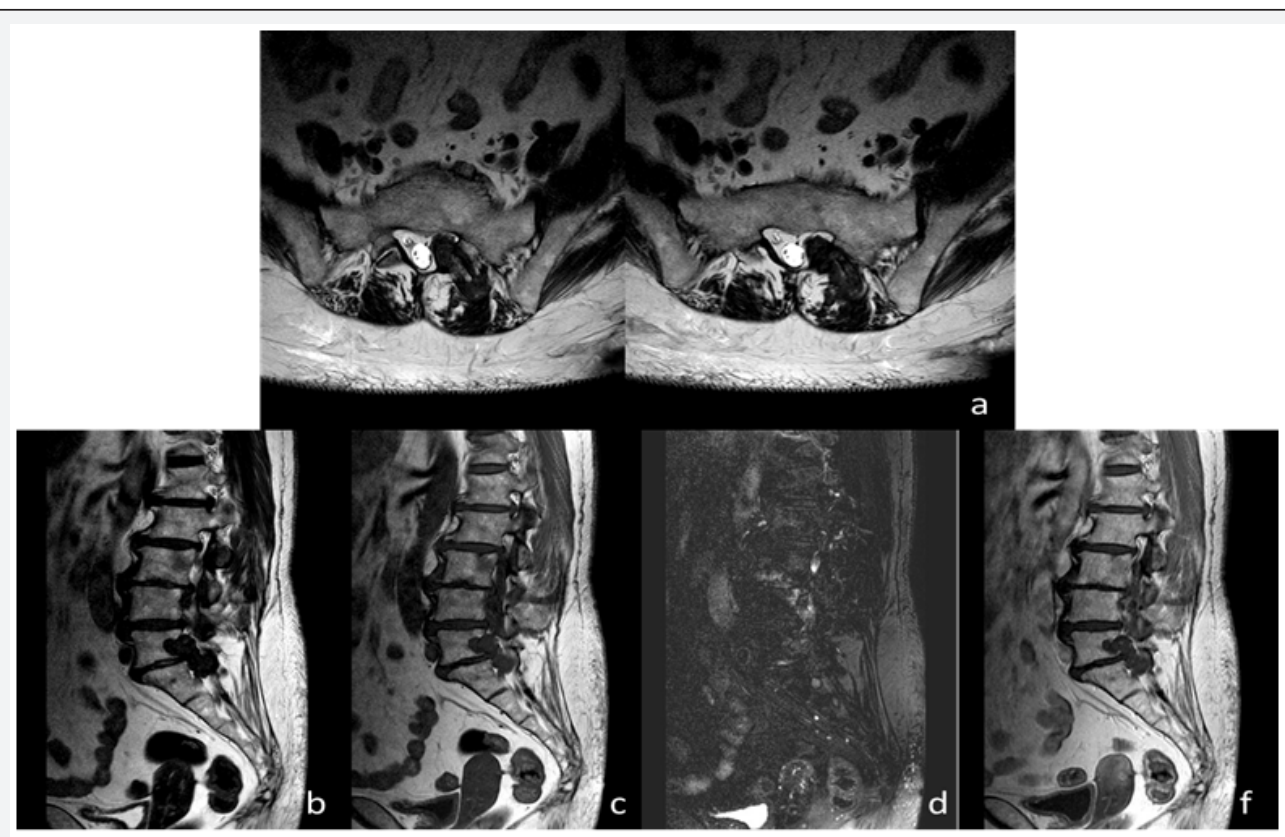

Figure 2: Axial T2 (a) and sagittal T2 (b), T1 (c), T2 FS (d) MRI demonstrate a mass centered around the left L5-S1 facet joint eroding the left posterior surface of the L5 vertebral body, left L5 pedicle, anterior and posterior surface of left L5-S1 facet joint. The mass consists of a tissue with predominantly hypointense signal on T2, T1 and T2 FS with little foci of contrast enhancement on T1 postcontrast images (f).

CT and MRI images (Figures 1 \& 2) demonstrate a heterogeneous mass centered on left L5-S1 facet joint with epidural extension and posterior paraspinal component. CT images show a few faint punctuate calcifications within a predominantly non-calcified mass causing chronic smooth erosion of left posterior cortex of the L5 vertebral body, left L5 pedicle, anterior and posterior surface of left L5-S1 facet joint. On MRI the mass consists of a tissue with predominantly dark signal on T1, T2 and T2 FS sequences with little foci of contrast enhancement. The epidural component of the mass spreads along the left anterior wall of the spinal canal, compresses the left S1 nerve root within the neural foramen. The posterior paraspinal component pushes back the left multifidus and longissimus thoracis muscle. The patient underwent the surgical removal of the tumor with osteoplasty of bone defect at the N.N. Blokhin National Medical Cancer Center.

\section{Histologic Findings of the Surgical Specimen}

Grossly, the pathology specimen consisted of nodular fragments of grey-white irregular structures that ranged from 3-14 $\mathrm{m}$ in largest dimension. The tissue looked mostly fleshy with some evidence of cartilage and granularity. Synovium was not obviously seen in the specimen. Microscopic sections revealed some isolated foci of dystrophic calcifications [6]. No surrounding reactive synovium was obviously seen. Discrete clusters of hyaline cartilage without evident cytologic atypia of chondrocytes were very characteristic for synovial chondromatosis. At high magnification, chondrocytes within cartilaginous myxoid matrix showed some occasional plump morphology and pleomorphism. All those features were more consistent with late phase of the development of synovial chondromatosis [7] (Figures 3-7).

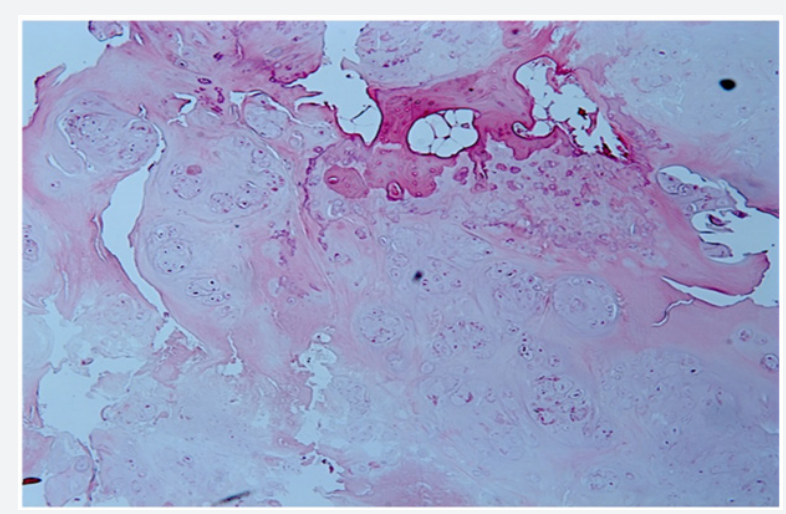

Figure 3: Localized synovial chondromatosis, especially in the late stage of its development, presents as conglomerate of individual cartilage nodules. At low power photomicrograph of the cross section through the lesion, most nodules are composed of hyaline cartilage. Some are calcified; some features of early enchondral ossification might be present. Hematoxylin-eosin X 200. 


\section{Orthopedics and Rheumatology Open Access Journal (OROAJ)}

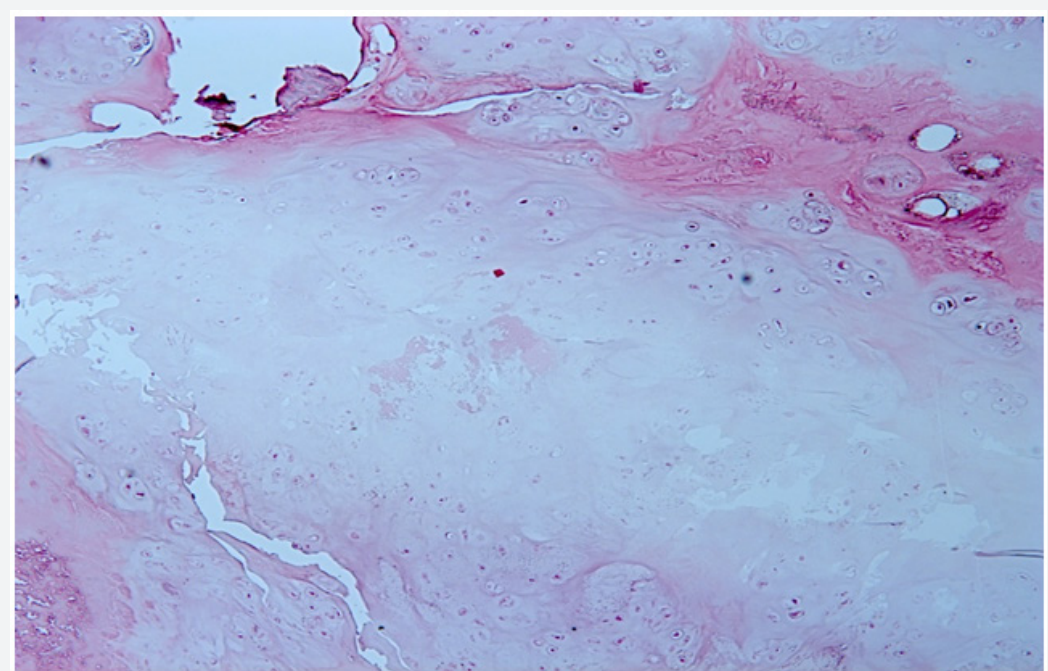

Figure 4: Degenerative changes of the matrix with local calcifications might be seen throughout the lesion. Hematoxylin-eosin X 200.

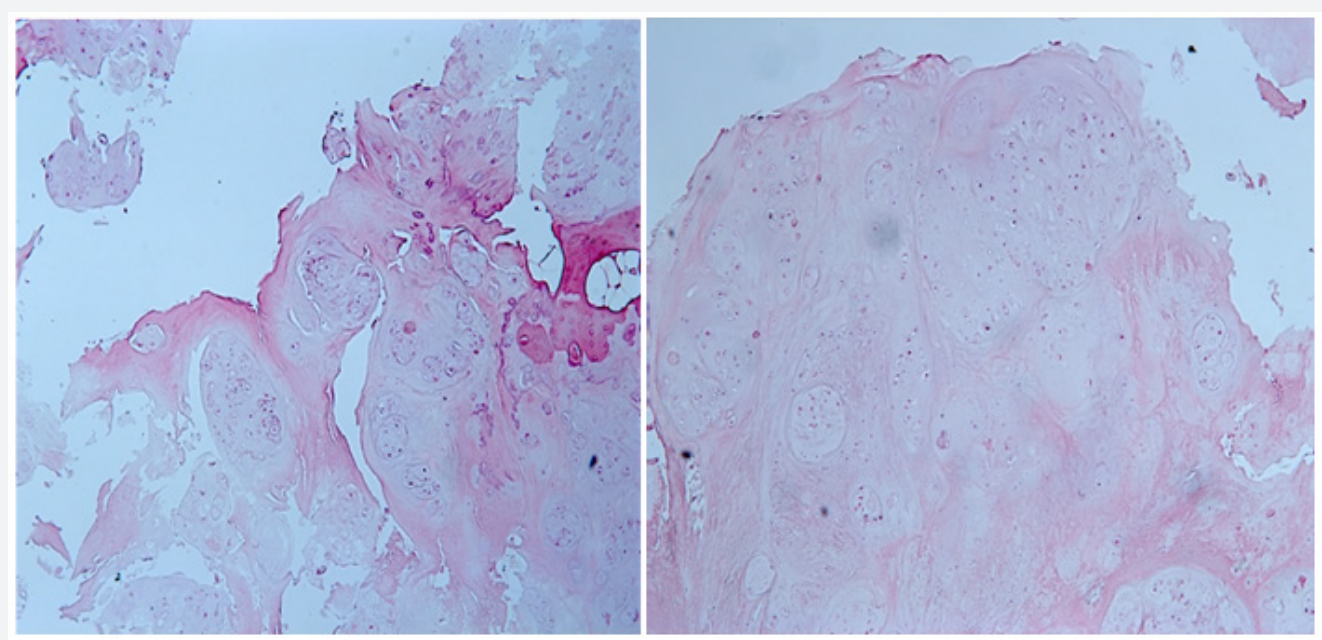

Figure 5: Well developed isles of chartilage tissue are very characteristic for the late, developed stage of synovial chondromatosis. The nodules may enlarge and detach from the synovium. Enchondral ossification of cartilage nodules is a frequent feature of well-developed synovial chondromatosis, even well-developed peripheral rings or eggshells of lamelar bone might be seen. Hematoxylin-eosin X 100.

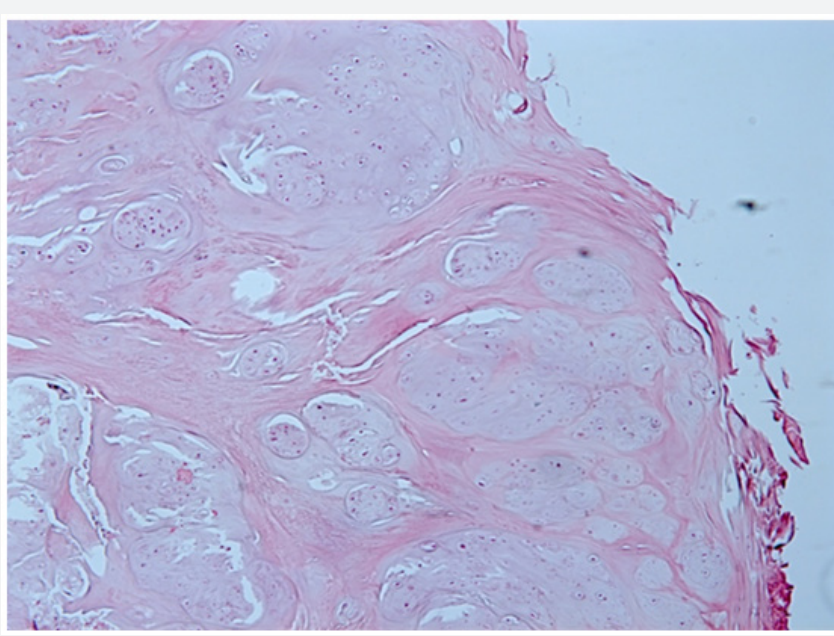

Figure 6: Medium power photomicrorraph of chondroid nodules, chondrocytes are clustered in lacune shape spaces, some myxoid areas are present, slight nuclear atypia and hyperchromasia might be seen. All those features are common for the well developed stage of synovial chondromatosis. Hematoxylin-eosin X 100. 

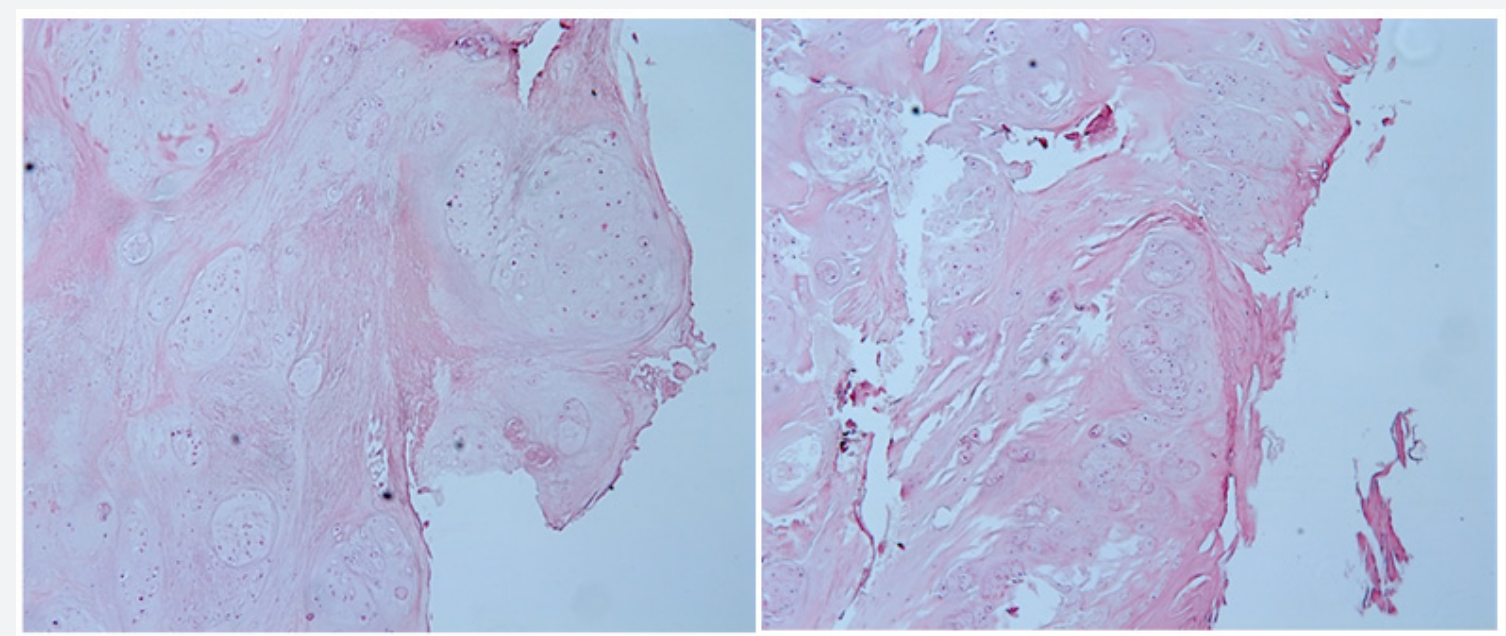

Figure 7: Dystrophic features, myxoid and chondroid matrix of the well developed nodules with some ischemic changes. Calcifications are throughout the lesion. Hematoxylin-eosin X 100.

\section{Discussion}

As it is seen in this case report, diagnosing synovial chondromatosis on frosen section or core biopsy can be difficult given the nondiagnostic findings of fibrous and synovial tissue, foci of dystrophic calcifications and reactive changes. When viewed in combination with proper clinical and radiographic information, synovial chondromatosis is likely to be diagnosed correctly. However, sinovial chondromatosis should be differentiated with various benign and malignant entities $[8,9]$. The differential list should include first of all chondrosarcoma. Chondroblastic cells in early stages of the development of sinovial chondromatosis might mimic several primary bone tumors and creat some difficulties for the pathologist. Features of the metaplastic nodules with clear cell features might mimic clear cell chondrosarcoma. Extensive cartilage metaplasia is always a diagnostic dilemma, and is often worrisome, especially if the biopsy is small. Tumoral calcinosis, degenerative joint disease, extraskeletal chondroma and hamartoma should always be considered in the differential. Prominent multifocal calcifications in the cartilages of joints and intervertebral disks are characteristic feature for tophaceous pseudogout (tumoral calcium pyrophosphate dehydrate crystal deposition disease) Making the correct diagnosis might be extremely difficult. Tumors that present as a single cartilaginous nodule within the joint capsule are sometimes reffered to as synovial chondromas.

Being a rare entity, synovial chondromatosis is demonstrating unusual and unexpected imaging findings in comparison with the well-known imaging features of synovial chondromatosis of the major joints of the appendicular skeleton [10]. The atypical features of presentation in the spine include extra osseous mass, little involvement of the adjacent facet joint. Chondromatosis masses usually did not center upon the facet joint, presence and pattern of chronic bony erosion is also characteristic $[8,9]$.

\section{Conclusion}

Primary synovial chondromatosis is a benign formation of islands of chondrocytes within the synovial lining of joints resulting in thickened synovium and forming subsynovial chondroid nodules. Synovial chondromatosis was initially classified as metaplasia, but more recent data prove the neoplastic nature of the process. Cartilage nodules may extrude through the synovium, detach, calcify and form so called loose bodies [11].

Numerous papers have been written about synovial chondromatosis in large joints, but limited reports of synovial chondromatosis of the spine reported in the literature. The purpose of our study was to review the radiographic and pathologic findings that can help to distinguish synovial chondromatosis of the spine from several benign and some malignant entities: tumoral calcinosis, degenerative joint disease, extraskeletal chondroma and hamartoma, tophaceous pseudogout, primary and secondary chondrosarcoma. Sinovial chondromatosis of the spine is rare, radiographic imaging has certain characteristic features. Only analysis of numerous cases can give the complete pisture of the changes in the spine joints. Therefore, it is essential to get a combination of data from clinician, radiologist and pathologist [6].

\section{References}

1. Kyriakos M, Totty WG, Riew KD (2000) Synovial chondromatosis in a facet joint of a cervical vertebra. Spine 25(5): 635-640.

2. Greenlee JD, Ghodsi A, Baumbach GL, VanGilder JC (2002) Synovial chondromatosis of the cervical spine case illustration. J Neurosurg 97(1): 150.

3. Littrell L, Inwards CY, Sim FH, Wenger DE (2016) Imaging features of synovial chondromatosis of the spine: a review of 28 cases. Skeletal Radiol 45(1): 63-71. 
4. Murphey MD, Vidal JA, Fanburg-Smith JC, Gajewski DA (2007) Imaging of synovial chondromatosis with radiologic-pathologic correlation. Radiographics 27(5): 1465-1488.

5. Inwards CY, Unni KK (2004) Bone tumors. In: Mills SE, Carter D, Greenson JK, Oberman HA, Reuter V, Stoler MH, (Eds), Sternberg's diagnostic surgical pathology. Lippincott Williams and Wilkins, Philadelphia, PA, USA, pp. 310-311.

6. Moody P, Bui MM, Vrionis F, Setzer M, Rojiani AM (2010) Synovial chondromatosis of spine: case report and review of the literature. Ann Clin Lab Sci 40(1): 71-74.

7. Bertoni F, Unni KK, Beabout JW, Sim FH (1991) Chondrosarcoma of the synovium. Cancer 67(1): 155-162.

This work is licensed under Creative Commons Attribution 4.0 License

DOI: 10.19080/OROAJ.2018.12.555829
8. Shives TC, McLeod RA, Unni KK, Schray MF (1989) Chondrosarcoma of the spine. J Bone Joint Surg Am 71(8): 1158-1165.

9. Fandburg-Smith J (2003) Cartilage and bone forming tumors and tumor- like lesions. In: Miettinen MM, editor. Diagnostic soft tissue pathology. Churchill Livingstone, New York, USA, pp. 405-406, 410411.

10. Gallia GL, Weiss N, Campbell JN, McCarthy EF, Tufaro AP, et al. (2004) Vertebral synovial chondromatosis. Report of two cases and review of the literature. J Neurosurg Spine 1(2): 211-218.

11. Unni KK, Inwards CY, Bridge JA, Kindblom LG, Wold LE (2005) Synovial tumors. Tumors of the bone and joints. Silver Spring, MDARP Press, USA pp. 386-432.

\section{Your next submission with Juniper Publishers will reach you the below assets}

- Quality Editorial service

- Swift Peer Review

- Reprints availability

- E-prints Service

- Manuscript Podcast for convenient understanding

- Global attainment for your research

- Manuscript accessibility in different formats

( Pdf, E-pub, Full Text, Audio)

- Unceasing customer service

Track the below URL for one-step submission https://juniperpublishers.com/online-submission.php 